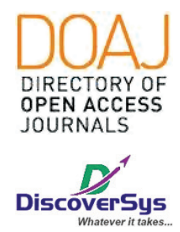

Published by DiscoverSys

\section{Uji antihiperglikemia ekstrak etanol daun sembung (Blumea balsamifera L.) terhadap tikus wistar jantan (Rattus norvegicus)}

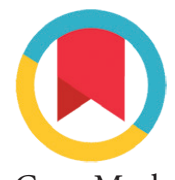

CrossMark

\author{
Sri Wahjuni, ${ }^{*}$ Nur Hafsia, Ni Wayan Bogoriani
}

\section{ABSTRACT}

Background: Sembung leaves (Blumea balsamifera L.) leaves are proven to contain flavonoid compositions that contain antihyperglycemic properties. This study aimed to evaluate effect of sembung leaves ethanol extract towards serum blood glucose of hyperglicemia wistar rats.

Method: This study includes the maintenance of test animals, fractionation and purification using TLC, column chromatography, and LCMS, free radical scavenging activity of 1.1-diphenyl-2-picrillhidrazil (DPPH) as well as experimental methods with pre-post test control group design. Twenty male Wistar rats (Rattus norvegicus) were divided into five groups, the negative control group (aquades), the positive control (glibenclamide $0.18 \mathrm{mg} /$ day $/ 200 \mathrm{gbw}$ ) and the test group with varying doses of $50 \mathrm{mg} / \mathrm{kgbw}, 100 \mathrm{mg} / \mathrm{kgbw}$, and $150 \mathrm{mg} /$ kgbw for 14 days and carried out measurement of blood sugar levels in rats. Rats collected data were analyzed using the One Way ANOVA test and continued with the LSD test.

Results: Result of LCMS management is flavonoid composition consisting of syringetin with $\mathrm{mz}=347$. In the free radical scavenging activity of DPPH ethylacetate fraction of Sembembal leaf extract $\mathrm{IC}_{50}$ value is $0.5369 \mu \mathrm{g} / \mathrm{ml}$ or $536.9 \mathrm{ppm}$. Data on rat blood regression levels were analyzed using the One Way ANOVA test and continued with the $L S D$ test each showing a value of $p=0.000$. This value indicates $a$ significant difference between each group $(p<0.05)$.

Conclusion: Ethanol fraction of sembung leaves can reduce protein levels in male wistar hyperglycemia rats. The secondary metabolism of syringetin contained in sembung leaves which contains antioxidants.

Program Studi Kimia, Fakultas MIPA Universitas Udayana, Jimbaran, Bali, Indonesia

*Korespondensi: Sri Wahjuni, Program Studi Kimia, Fakultas MIPA Universitas Udayana, Jimbaran, Bali, Indonesia

sriwahjunimanuaba@gmail.com

Diterima: 02-12-2019

Disetujui: $26-06-2020$

Diterbitkan: 01-08-2020

Keywords: Sulfuric leaf ethanol extract, antihyperglycemic test, male wistar rats.

Cite This Article: Wahjuni, S., Hafsia, N., Bogoriani, N.W. 2020. Uji antihiperglikemia ekstrak etanol daun sembung (Blumea balsamifera L.) terhadap tikus wistar jantan (Rattus norvegicus). Intisari Sains Medis 11(2): 582-589. D0I: 10.15562/ism.v11i2.670

\title{
ABSTRAK
}

Latar belakang: Blumea balsamifera (daun sembung) terbukti memiliki senyawa flavonoid dengan khasiat antihiperglikemik. Penelitian ini guna mengkaji efek pemberian ekstrak etanol daun sembung terhadap penurunan kadar glukosa darah pada tikus wistar jantan yang hiperglikemia.

Metode: Penelitian ini meliputi pemeliharaan hewan uji, fraksinasi, dan pemurnian menggunakan metode KLT, kromatografi kolom, dan LCMS, uji aktivitas pengikatan radikal bebas 1,1-diphenyl-2-picrylhydrazyl (DPPH) serta metode eksperimental dengan pre-post test control group design. Dua puluh ekor tikus wistar jantan (Rattus norvegicus) dibagi menjadi lima kelompok, kelompok kontrol negatif (aquades), kontrol positif (glibenclamide 0,18 mg/hari $/ 200 \mathrm{gBB}$ ) dan kelompok uji dengan variasi dosis fraksi etilasetat ekstrak etanol daun sembung $50 \mathrm{mg} / \mathrm{kgbb}, 100$ $\mathrm{mg} / \mathrm{kgbb}$ dan $150 \mathrm{mg} / \mathrm{kgbb}$ selama 14 hari dan dilakukan pengukuran kadar gula darah pada tikus. Data kadar glukosa tikus dianalisis dengan menggunakan uji One Way ANOVA dan dilanjutkan dengan uji LSD. Pada penelitian ini didapatkan hasil dari fragementasi LCMS adalah senyawa flavonoid yang berupa syringetin dengan $\mathrm{mz}=347$.

Hasil: Pada evaluasi aktivitas pengikatan radikal bebas DPPH fraksi etilasetat ekstrak etanol daun sembung memiliki nilai $I_{50}$ adalah 0,5369 $\mu \mathrm{g} / \mathrm{ml}$ atau 536,9 ppm. Data kadar glukosa darah tikus yang dianalisis dengan menggunakan uji One Way ANOVA dan dilanjutkan dengan uji LSD masing-masing menunjukkan nilai $p=0,000$. Nilai ini memperlihatkan perbedaan signifikan antar tiap kelompok intervensi $(p<0,05)$.

Simpulan: Fraksi ekstak etanol daun sembung dapat menurunkan kadar glukosa darah pada tikus wistar jantan yang hiperglikemia. Penurunan glukosa darah ini diduga berasal dari metabolit sekunder syringetin yang terkandung dalam daun sembung yang berperan sebagai antioksidan.

Kata Kunci: Ekstrak etanol daun sembung, uji antihiperglikemik, tikus wistar jantan.

Cite Pasal Ini: Wahjuni, S., Hafsia, N., Bogoriani, N.W. 2020. Uji antihiperglikemia ekstrak etanol daun sembung (Blumea balsamifera L.) terhadap tikus wistar jantan (Rattus norvegicus). Intisari Sains Medis 11(2): 582-589. D01: 10.15562/ism.v11i2.670

\section{PENDAHULUAN}

Diabetes melitus adalah salah satu penyakit yang banyak menyerang masyarakat dunia dengan prevalensi meningkat secara dramatis selama dua dekade terakhir menjadi 382 juta kasus pada tahun 
2013. Pentakit ini ditandai dengan adanya hiperglikemia yang merupakan suatu kondisi dengan kadar glukosa dalam plasma darah melebihi batas normal. ${ }^{1,2}$ Produksi radikal bebas yang berlebihan menjadi penyebab hiperglikemia sehingga memicu terjadinya stress oksidatif. ${ }^{3}$ Senyawa, vitamin maupun mineral yang bersifat antioksidan dapat menetralkan dan mengikat radikal bebas. ${ }^{4}$ Flavonoid merupakan senyawa yang berfungsi sebagai antioksidan yang dapat menangkal kerusakan sel tubuh yang disebabkan oleh radikal bebas sehingga dapat berperan dalam mencegah terjadinya beberapa penyakit degene-ratif, salah satunya yakni penyakit diabetes melitus. ${ }^{5}$

Efek samping yang dihasilkan oleh obat hiperglikemia saat ini menyebabkan peminat obat herbal untuk penyakit diabetes melitus meningkat. Daun sembung (Blumea balsamifera L. adalah salah satu bahan obat tradisional yang mengan-dung senyawa antioksidan dan diindikasikan sebagai obat penyakit diabetes melitus. ${ }^{6}$ Daun merupakan bagian tanaman Blumea balsamifera yang paling sering digunakan, sebab mengandung flavonoid yang dapat bertindak sebagai penangkap radikal hidroksil sehingga mencegah aksi diabeta-gonik dari aloksan. ${ }^{7}$

Hasil penelitian aktivitas antidiabetes ekstrak daun sembung pada kelinci dengan metode pembebanan glukosa peroral menyatakan bahwa senyawa dalam daun sembung yang berpotensi sebagai antidiabetes larut dalam pelarut yang bersifat polar. ${ }^{8}$ Glukosa darah berlebih dalam kasus diabetes melitus akan bereaksi dengan hemoglobin melalui proses nonenzimatik menjadi hemoglobin glokosilat. Peningkatan hemoglobin glikosilat pada tikus yang diinduksi streptozotocin dapat diturunkan secara signifikan oleh ekstrak Blumea balsamifera. ${ }^{9}$ Aktivitas enzim aldose reduktase pada tikus dihambat oleh komponen flavonoid ekstrak Blumea balsamifera sehingga mencegah komplikasi pada penyakit diabetes. ${ }^{10}$ Berdasarkan uraian tersebut, penelitian ini akan mengkaji efek pemberian ekstrak etanol daun sembung (Blumea balsamifera L.) terhadap penurunan kadar glukosa darah pada tikus wistar jantan (Rattus norvegicus) yang hiperglikemia.

\section{METODE PENELITIAN}

\section{Bahan dan peralatan}

Bahan yang digunakan dalam penelitian ini antara lain; daun sembung (Blumea balsamifera L.) etanol 96\%, metanol, 1,1-diphenyl-2-picrylhydrazyl (DPPH), $\mathrm{FeCl}_{3}$, kuersetin, logam magnesium, $\mathrm{HCl}$, $\mathrm{HgCl}_{2}, \mathrm{KI}$, asam asetat anhidrat, asam sulfat pekat,
$\mathrm{NaOH}$, tikus Wistar jantan, pakan standar 501, obat bius, streptozotocin, glibenclamide, pelat silica gel $\mathrm{GF}_{254}$ akuades, silica gel 60, n-heksana, etil asetat dan air. Peralatan yang digunakan dalam penelitian ini antara lain: liquid chromatography-mass spectrometry (LC-MS), lampu UV, spektrofotometer UV-VIS, dan rotary vacum evaporator.

\section{METODE}

\section{Determinasi}

Dilakukan determinasi pada daun sembung (Blumea balsamifera L.) di LIPI (Lembaga Ilmu Pengetahuan Indonesia) Kebun Raya Eka Karya Bali.

\section{Persiapan bahan}

Sampel daun sembung dicuci menggunakan air bersih dan ditiriskan. Daun kemudian dipotong kecil-kecil dan dikeringkan dengan cara diangin-anginkan, tanpa terkena sinar matahari. Sampel daun sembung yang kering selanjutnya dihaluskan menggunakan blender dan ditimbang dengan neraca analitik.

\section{Penentuan kadar air simplisia daun sembung (Blumea balsamifera $L$.)}

Serbuk daun sembung ditimbang sebanyak 3 gram di dalam wadah yang telah diketahui bobo-tnya. Simplisia daun sembung dikeringkan pada suhu $105^{\circ} \mathrm{C}$ selama $2 \mathrm{jam}$ dan didinginkan di desikator lalu ditimbang kembali. Pengeringan dilanjutkan hingga diperoleh bobot konstan.

\section{Ekstraksi daun sembung (Blumea balsamifera $\mathrm{L}$.)}

Sebanyak $1 \mathrm{~kg}$ serbuk daun sembung (Blumea balsamifera L.) diekstraksi melalui maserasi dengan pelarut etanol selama \pm 24 jam. Filtrat hasil maserasi disaring, kemudian residunya dimaserasi kembali dengan cara yang sama hingga diperoleh filtrat bening. Filtrat bening ditotolkan pada plat KLT untuk mengetahui semua senyawa aktif dalam serbuk daun sembung telah habis. Ekstrak etanol disaring dan dipisahkan dari pelarutnya dengan rotary vacuum evaporator hingga diperoleh ekstrak kental etanol daun sembung.

\section{Skrining fitokimia ekstrak etanol daun sembung (Blumea balsamifera $\mathrm{L}$.)}

Uji fitokimia dilakukan untuk mengiden-tifikasi keberadaan senyawa metabolit sekunder pada ekstrak etanol daun sembung meliputi uji polifenol, uji flavonoid, uji saponin, uji alkaloid, dan uji steroid. 


\section{Uji Aktivitas pengikatan radikal bebas 1,1-diphenyl-2-picrylhydrazyl (DPPH)}

Ekstrak etanol daun sembung diuji aktivitas antioksidannya dengan metode DPPH $(0,004 \%$ dalam methanol). Larutan induk dibuat variasi konsentrasi 1,$1 ; 2,2 ; 3,34$; dan 4,45 ppm sebagai larutan uji masing-masing $5 \mathrm{ml}$. Sebanyak $200 \mu \mathrm{l}$ larutan uji dimasukkan ke dalam kuvet kemudian ditambahkan larutan DPPH sebanyak $3 \mathrm{ml}$ lalu dihomogenkan. Campuran didiamkan selama 30 menit dan diukur absorbansinya pada panjang gelombang maksimal. Metanol digunakan sebagai blangko. Aktivitas penangkap radikal DPPH (\%) dihitung dengan rumus berikut:

$\% \mathrm{DPPH}=\frac{\text { Abs kontrol - Abs sampel }}{\text { Abs kontrol }} \times 100 \%$

\section{Fraksinasi ekstrak daun sembung (Blumea balsamifera L.)}

Ekstrak etanol daun sembung difraksinasi bertingkat menggunakan tiga pelarut yang berbeda kepolarannya yaitu n-heksana, etil asetat, dan

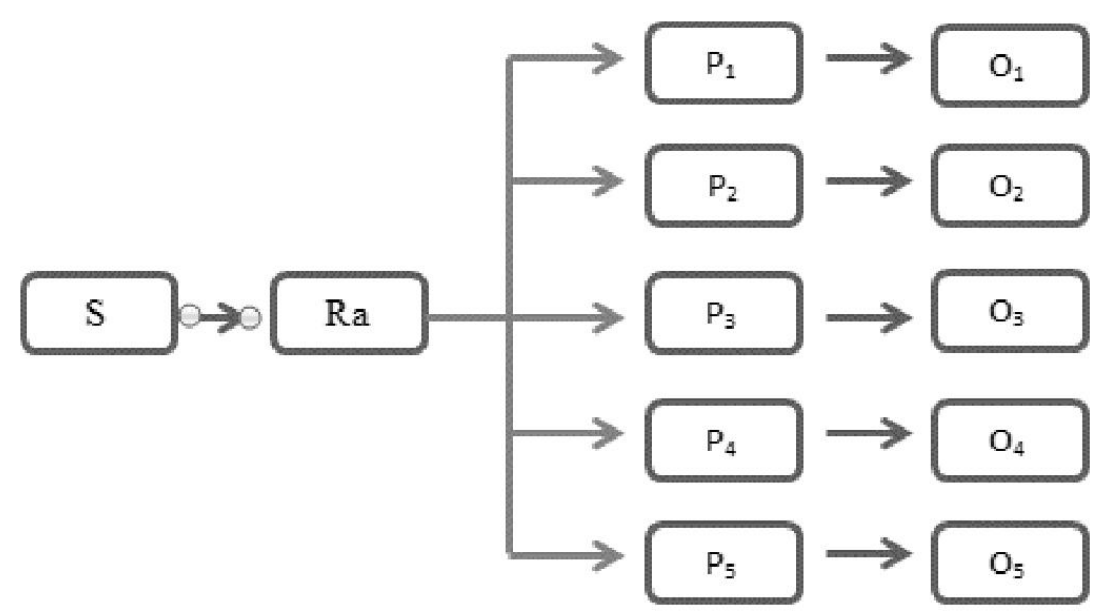

Gambar 1 Bagan Rancangan Penelitian

$$
\begin{aligned}
& \text { Keterangan: } \\
& \mathrm{S} \quad=\text { sampel } \\
& \mathrm{Ra}=\text { randomisasi } \\
& \mathrm{P}_{1}=\text { kontrol negatif }(4 \text { tikus wistar })+\text { pakan standar } 501+
\end{aligned}
$$

air dalam corong pisah. Sebanyak $20 \mathrm{~g}$ ekstrak etanol daun sembung dilarutkan dalam campuran etanol-air dengan perbandinga 7:3, kemudian ditambahkan pelarut $n$-heksan sampai didapatkan fraksi air (bawah) dan fraksi n-heksan (atas), lalu lapisan n-heksana dipisahkan dari lapisan air. Ekstrak n-heksana lalu diuapkan dengan rotary vacum evaporator pada suhu $40^{\circ} \mathrm{C}$ hingga diperoleh ekstrak kental n-heksana. Lapisan air kemudian difraksinasi kembali menggunakan etil asetat sampai didapat lapisan etil asetat (atas) dan lapisan air (bawah) kemudian pidahkan kedua lapisan tersebut. Ekstrak etil asetat dan ekstrak air kemudian diuapkan dengan rotary vacum evaporator pada suhu $40^{\circ} \mathrm{C}$ hingga diperoleh ekstrak kental etil asetat dan ekstrak kental air.

\section{Pemurnian dan identifikasi}

Proses pemurnian dan identifikasi dilakukan dengan metode kromatografi lapis tipis (KLT), kromatografi kolom, kromatografi lapis tipis pemurnian, dan analisis dengan teknik LC-MS.

\section{Rancangan penelitian}

Penelitian ini menggunakan metode true experimental dengan bentuk randomized pre-post test control group design. Adapun bagan rancangan penelitian dijelaskan pada Gambar 1.

\section{Perlakuan hewan uji}

Selepas adaptasi dalam kurun waktu 1 minggu, subjek penelitian dibagi menjadi 5 kelompok. Kelompok $\mathrm{P}_{1}$ sebagai kelompok kontrol negatif yang diberi pakan standar 501 secara teratur. Hari pertama dilakukan pengukuran kadar glukosa darah sebagai pengukuran kadar glukosa awal. Kelompok $\mathrm{P}_{1}, \mathrm{P}_{2}, \mathrm{P}_{3}, \mathrm{P}_{4}$, dan $\mathrm{P}_{5}$ diberikan pakan standar 501 dan dibuat hiperglikemia dengan pemberian injeksi streptozotocin dosis tunggal $40 \mathrm{mg} / \mathrm{kgbb}$ secara intraperitoneal. Sebelum penginduksian diabetes, semua tikus wistar dipuasakan makan selama \pm 8 jam (air minum tetap diberikan secukupnya). Tikus wistar dipelihara dan diberi minum yang mengandung glukosa 5\% selama satu hari, sedangkan untuk hari-hari selanjutnya tanpa glukosa. Pada hari ke 3 setelah diinjeksi streptozotocin, kadar glukosa tikus diukur kembali untuk membandingkan dengan kadar glukosa awal, yaitu sebelum dilakukan injeksi streptozotocin. Tikus wistar diabetes yang dipakai dalam penelitian ini adalah tikus wistar yang mempunyai kadar glukosa darah ${ }^{3} 200 \mathrm{mg} / \mathrm{dl}$ yang dikelompokan secara acak.

Setelah 3 hari (hari keempat) kelompok tikus $\mathrm{P}_{2}, \mathrm{P}_{3}$ dan $\mathrm{P}_{4}$ diberi intervensi ekstrak etanol daun sembung dengan berbagai dosis dengan variasi dosis $50 \mathrm{mg} / \mathrm{kgbb}$ untuk kelompok $\mathrm{P}_{2}, 100 \mathrm{mg} / \mathrm{kgbb}$ untuk kelompok $\mathrm{P}_{3}$, dan $150 \mathrm{mg} / \mathrm{kgbb}$ untuk 
kelompok $\mathrm{P}_{3}$. Untuk kelompok $\mathrm{P}_{5}$ diberi glibenclamide $0,18 \mathrm{mg} / \mathrm{hari} / 200 \mathrm{gbb}$ selama 14 hari. Kelompok tikus $\mathrm{P}_{2}, \mathrm{P}_{3}, \mathrm{P}_{4}$ dan $\mathrm{P}_{5}$ diberikan pakan standar 501 dengan penambahan diet ekstrak etanol daun sembung per oral selama 14 hari. Setelah 14 hari dilakukan pengujian dan penentapan penurunan kadar glukosa darah.

\section{Pemeriksaan kadar glukosa dalam darah tikus}

Sebelum dilakukan pengambilan darah, bagian ekor tikus wistar dibersihkan terlebih dahulu menggunakan alkohol 70\%. Selanjutnya darah diambil pada bagian vena ekor tikus menggunakan autokilk. Pengukuran kadar gula darah pada tikus Wistar menggunakan alat tes glukosa GLUKO M dilakukan sebelum induksi streptozotocin, sesudah induksi streptozotocin dan setelah diberi intervensi ekstrak etanol daun sembung dalam berbagai dosis.

\section{Analisis hasil}

Data hasil penelitian dianalisis secara statistik menggunakan uji ANOVA dengan program Statistical Product and Services Solution (SPSS) menggunakan software SPSS 23.0 for Windows dengan tingkat kepercayaan 95\%. Tahapan analisis data meliputi uji normalitas, uji homogenitas, dan uji komparasi yang kemudian dilanjutkan dengan Post Hoc test dengan uji LSD. ${ }^{11}$

\section{HASIL}

\section{Kadar air}

Kadar air simplisia daun sembung didapatkan 9,37\%, yaitu telah memenuhi syarat standar mutu dari DEPKES RI untuk obat herbal Indonesia yaitu maksimal 10\% (Tabel 1).

\section{Tabel 1 Data kadar air}

\begin{tabular}{lcc}
\hline No & Pengulangan & Kadar air (\%) \\
\hline 1 & I & 9,34 \\
2 & II & 9,38 \\
3 & III & 9,41 \\
\hline
\end{tabular}

Tabel 2 Hasil uji fitokimia esktrak etanol daun sembung

\begin{tabular}{lc}
\hline Uji fitokimia & Hasil \\
\hline Polifenol & + \\
Flavonoid & + \\
Saponin & + \\
Alkaloid (Meyer) & - \\
Alkaloid (Dragendorf) & + \\
Steroid & + \\
\hline
\end{tabular}

\section{Ekstraksi daun sembung}

Simplisia daun sembung sebanyak $1 \mathrm{~kg}$ dimaserasi menggunakan etanol 96\%. Etanol dipilih karena sifatnya yang polar, yaitu pada prinsipnya senyawa akan larut dengan pelarut yang memiliki kepolaran yang sama. Hasil maserasi simplisia daun sembung didapatkan 142,63 gram ekstrak kental dengan rendaman sebesar $14,26 \%$.

\section{Skrining fitokimia ekstrak etanol daun sembung (Blumea balsamifera L.)}

Pada uji polifenol ekstrak etanol daun sembung direaksikan dengan $\mathrm{FeCl}_{3}$ 10\% menunjukkan hasil positif yang ditandai dengan warna hijau kehitaman yang terbentuk dari senyawa kompleks antara polifenol dan $\mathrm{FeCl}_{3}$. Terbentuknya garam flavilium yang bewarna merah dengan penambahan serbuk $\mathrm{Mg}$ dan $\mathrm{HCl}$ pekat menandakan ektrak etanol mengandung flavonoid. Identifikasi saponin dengan $\mathrm{HCl}$ 0,2 M pada ekstrak etanol daun sembung menunjukkanhasil positif dengan busa yang tak hilang.

Uji alkaloid dengan menggunakan pereaksi Meyer menunjukkan hasil yang negatif namun pada saat direaksikan dengan pereaksi Dragendorf terbentuk endapan warna jingga yang diakibatkan oleh penggantian ligan $\mathrm{N}$ yang memiliki elektron yang bebas membentuk ikatan kovalen koordinasi. Uji steroid dan triterpenoid menghasilkan larutan berwarna hijau dengan penambahan pereaksi Liebermann-Bouchard (asam asetat anhidrat- $\mathrm{H}_{2} \mathrm{SO}_{4}$ ) Hasil uji fitokimia lebih lengkap dapat dilihat pada Tabel 2.

\section{Uji Aktivitas pengikatan radikal bebas DPPH (1,1-diphenyl-2-picrylhydrazyl)}

Ekstrak etanol daun sembung diuji aktivitas pengikatan radikal bebasnya dengan menggunakan metode DPPH (1,1-diphenyl-2-picrylhydrazyl).

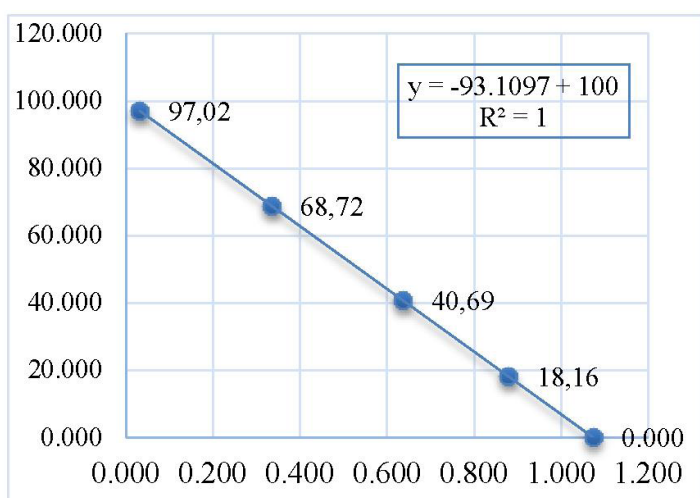

Gambar 2 Grafik hubungan antara konsentrasi hasil ekstrak etanol daun sembung dengan\% penghambatan terhadap $\mathrm{DPPH}$ 
Tabel 3 Hasil pengukuran aktivitas antioksidan ekstrak etanol daun sembung dengan DPPH

\begin{tabular}{lcc}
\hline Konsentrasi sampel $\boldsymbol{\mu g} / \mathbf{m l}$ & Absorbansi sampel & \% IC \\
\hline 0,00 & 1,074 & 0,000 \\
1,11 & 0,879 & 18,16 \\
2,22 & 0,637 & 40,69 \\
3,34 & 0,336 & 68,72 \\
4,45 & 0,032 & 97,02 \\
\hline
\end{tabular}

Tabel 4 Hasil uji kemurnian fraksi 4 berbagai fase gerak

\begin{tabular}{lcc} 
Fase gerak & Jumlah noda & Nilai Rf \\
\hline Etanol:n-heksana:etil asetat (2:5:3) & 1 & 0,97 \\
Etanol:kloroform:n-heksana (2:3:5) & 1 & 0,96 \\
Etil asetat:kloroform:n-heksana (2:3:5) & 1 & 0,95 \\
\hline
\end{tabular}

Tabel 5 Kadar gula darah pretest dan posttest

\begin{tabular}{lccc}
\hline & \multicolumn{3}{c}{ Hasil pengujian kadar glukosa darah $(\mathbf{m g} / \mathbf{d L})$} \\
\cline { 2 - 4 } Perlakuan & $\begin{array}{c}\text { Pretest } \\
\text { rerata } \pm \text { SD }\end{array}$ & $\begin{array}{c}\text { PostTest } \\
\text { rerata } \pm \text { SD }\end{array}$ & $\begin{array}{c}\text { Selisih kadar glukosa } \\
\text { darah rerata } \pm \text { SD }\end{array}$ \\
\hline P1 & $222,5 \pm 7$ & $549,25 \pm 48,95$ & $326,75 \pm 45,78^{\mathrm{b}, \mathrm{c}, \mathrm{d}, \mathrm{e}}$ \\
P2 & $233 \pm 10,5515$ & $200,75 \pm 12,28$ & $32,25 \pm 2,50^{\mathrm{a}, \mathrm{c}, \mathrm{d}, \mathrm{e}}$ \\
P3 & $217 \pm 6,6833$ & $132,50 \pm 9,67$ & $84,50 \pm 4,44^{\mathrm{a}, \mathrm{b}, \mathrm{d}, \mathrm{e}}$ \\
P4 & $278,5 \pm 8,6602$ & $109 \pm 8,28$ & $160,50 \pm 8,35^{\mathrm{a}, \mathrm{b}, \mathrm{c}, \mathrm{e}}$ \\
P5 & $299,75 \pm 9,4648$ & $97,5 \pm 6,75$ & $202,25 \pm 15,20^{\mathrm{a}, \mathrm{b}, \mathrm{c}, \mathrm{d}}$ \\
\hline
\end{tabular}

Keterangan:

${ }^{a}$ menunjukkan perbedaan nyata dari kelompok P1 pada $\mathrm{p}<0,05$

${ }^{b}$ menunjukkan perbedaan nyata dari kelompok P2 pada $p<0,05$

${ }^{c}$ menunjukkan perbedaan nyata dari kelompok $\mathrm{P} 3$ pada $\mathrm{p}<0,05$

${ }^{d}$ menunjukkan perbedaan nyata dari kelompok P4 pada $\mathrm{p}<0,05$

${ }^{e}$ menunjukkan perbedaan nyata dari kelompok P5 pada $\mathrm{p}<0,05$

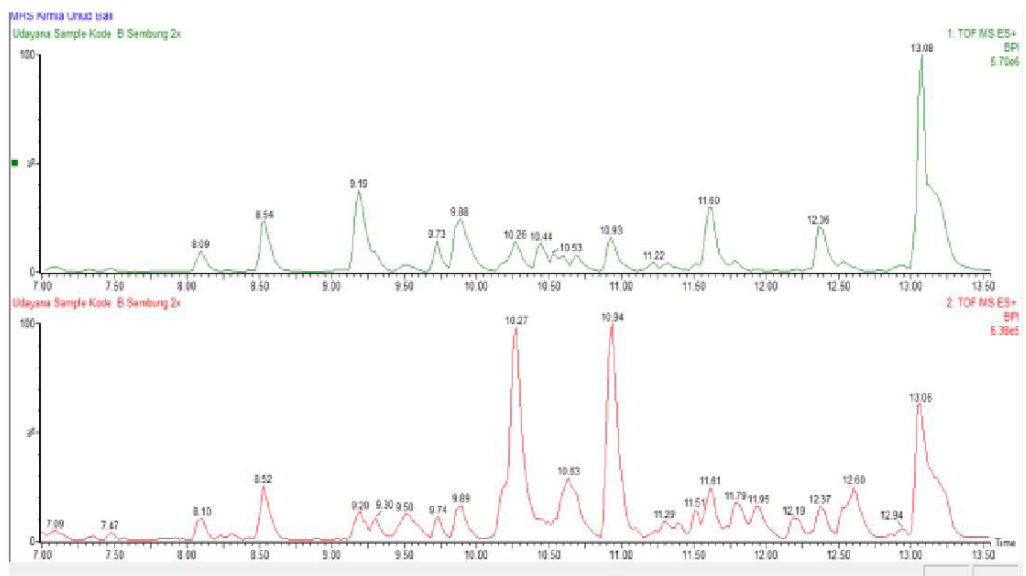

Gambar 3 Kromatogram LC-MS fraksi 4

Hasil pengukuran aktioksidan ekstrak etanol daun sembung dengan metode DPPH disajikan pada Tabel 3.
Pengujian aktivitas antioksidan didasarkan pada peredaman ketika DPPH direaksikan dengan senyawa antiradikal terjadi penangkapan hidrogen yang menghasilkan warna kuning. Aktivitas antioksidan dari ekstrak etanol daun sembung dinyatakan sebagai $\mathrm{IC}_{50}$ (inhibitiory consentration) yaitu nilainya didapatkan dari persamaan regresi linear. Nilai $\mathrm{IC}_{50}$ akan naik seiringan dengan konsentrasi dari sampel yang ikut naik, hal ini terjadi akibat jumlah antioksidan yang terkandung dalam sampel meredam radikal bebas semakin tinggi. Gambar 2 menunjukkan hubungan antara konsentrasi hasil ekstrak etanol daun sembung dengan\% penghambatan terhadap DPPH.

Pada penelitian ini nilai $\mathrm{IC}_{50}$ ekstrak etanol daun sembung memiliki tingkat aktivitas aktioksidan yang sangat kuat yaitu $0,5369 \mu \mathrm{g} / \mathrm{ml}$. Senyawa dapat dikatakan memiliki aktivitas antioksidan yang kuat jika memiliki nilai $\mathrm{IC}_{50}$ yang kurang dari $10 \mu \mathrm{g} / \mathrm{mL} .^{12}$

\section{Partisi ekstrak daun sembung (Blumea balsamifera L.)}

Fraksinasi dengan ekstraksi cair-cair memiliki prinsip pemisahan suatu senyawa pada sampel tertentu berdasrkan berat jenis dari dua pelarut yang tidak bercampur. Pelarut yang dipakai pada partisi kali ini yaitu etil asetat, n-heksana, dan air. Partisi menggunakan pelarut yang berbeda-beda kepolarannya agar senyawa metabolit sekunder pada sampel dapat terikat sesuai tingkat kepolaran dari pelarut yang digunakan. Fraksi yang telah di dapatkan kemudian dievaporasi hingga didapatkan ekstrak yang kental dari masing-masing fraksi. Rendemen ekstrak kental dari fraksi n-hexan didapatkan sebesar $19,80 \%$ dan $16,35 \%$ untuk fraksi etil asetat dan 6,95\% untuk fraksi air.

\section{Pemurnian dan identifikasi}

Sebelum ekstrak kental dimurnikan dan diidentifikasi, dilakukan penentuan eluen yang mempunyai pemisahan yang terbaik terhadap sampel yang nantinya eluen terbaik akan digunakan sebagai eluen diproses kromatografi lapis tipis (KLT) dan kromatografi kolom. N-hexan dan etil asetat digunakan sebagai fase gerak dengan variasi perbandingan volume $\mathrm{n}$-heksana:etil asetat $(2,5: 7,5 ; 8: 2$; $7,5: 2,5 ; 2: 8 ; 7: 3 ; 5: 5 ; 4: 6 ; 9: 1$; dan $1: 9)$ serta etil asetat:n-heksan $7: 3$. Spot yang muncul dari hasil elusi diamati dibawah sinar UV pada panjang gelombang $254 \mathrm{~nm}$ dan $365 \mathrm{~nm}$. Fraksi etil asetat dengan eluen $n$-heksana:etil asetat (7:3) memberikan pemisahan yang terbaik dengan 10 noda dan nilai Rf noda antara 0,03 hingga 0,95.

Ekstrak kental fraksi etil asetat daun sembung dipisahkan dengn metode kromatografi kolom. 


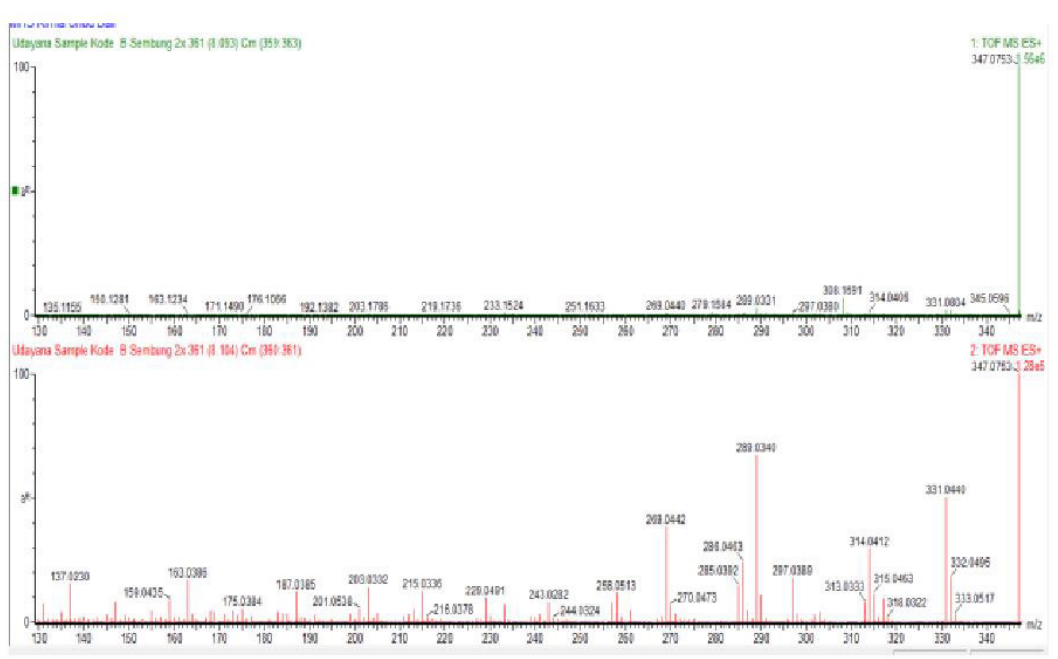

Gambar 4 Spektrum massa puncak dengan $t_{R} 8,10$ menit

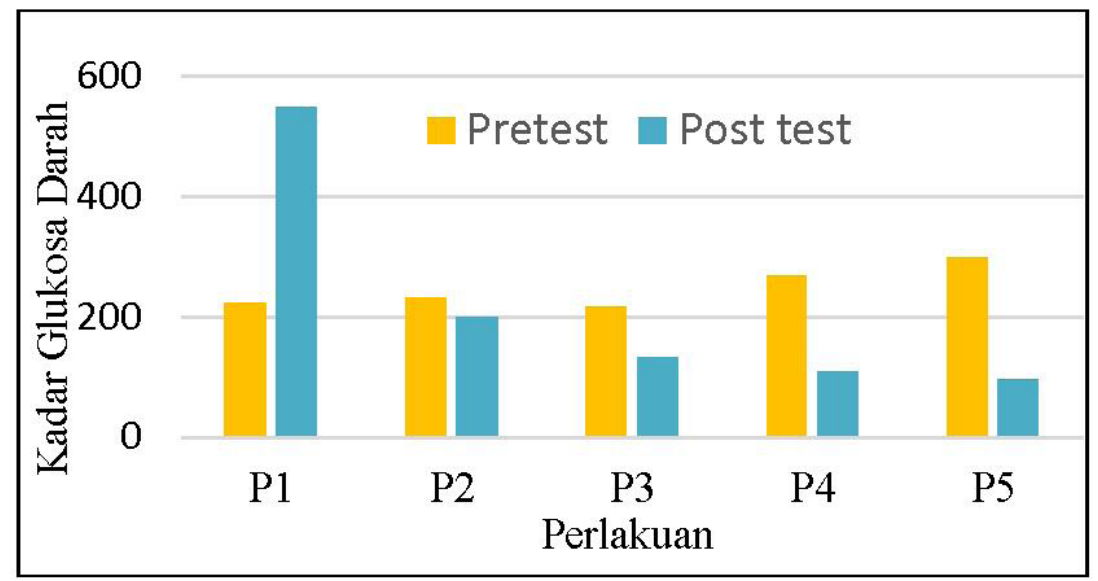

Gambar 5 Diagram rerata kadar glukosa darah sebelum dan sesudah pemberian fraksi etil asetat ekstrak daun sembung

N-heksana: etil asetat (7:3) digunakan sebagai fase gerak dan silica gel sebagai fase diamnya kemudian didispersikan hingga menjadi bubur dan dimasukkan kedalam kolom lalu dibiarkan mengendap. Kecepatan dari aliran fraksi diatur agar kepadatan adsorben di dalam kolom tetap sama. Ekstrak kental fraksi etil asetat dilarutkan dengan etanol dan dielusi kedalam kolom kromatografi. Hasil elusi didapatkan 80 botol vial eluat yang kemudian diuji dengan menggunakan KLT. Tujuan dari pengujian KLT untuk mengetahui pola dari noda hasil pemisahan kromatografi kolom. Eluat yang memiliki pola yang sama digabungkan dan didapatkan 19 fraksi dengan noda yang sama. Seluruh fraksi tersebut kemudian diuji flavonoidnya dengan $\mathrm{NaOH} 10 \%$, fraksi dengan noda tunggal dilanjutkan keuji kemurnian. Fraksi 4 memberikan pola noda tunggal yang cukup jelas dengan beberapa macam eluen. Hasil uji kemurnian fraksi 4 ditunjukkan pada Tabel 4. Fraksi 4 kemudian diidentifikasi jenis flavonoidnya dengan menggunakan metode LC-MS/MS dan didapatkan kromatogram seperti pada Gambar 3. Spektrum puncak yang muncul kemudian dikonfirmasi ke dalam database. Hasil interpretasi diduga senyawa yang terdapat pada fraksi 4 ekstrak daun sembung adalah syringetin dengan rumus molekul $\mathrm{C}_{17} \mathrm{H}_{14} \mathrm{O}_{8}$ dan berat molekul 347 (Gambar 4).

Dugaan senyawa flavonoid muncul pada waktu retensi 8,10 menit dengan puncak ion molekuler $[\mathrm{M}+\mathrm{H}]^{+}$pada $\mathrm{m} / \mathrm{z} 347$ sebagai puncak dasar, sedangkan puncak-puncak penggalannya adalah $331 \mathrm{~m} / \mathrm{z}, 314 \mathrm{~m} / \mathrm{z}, 285 \mathrm{~m} / \mathrm{z}, 269 \mathrm{~m} / \mathrm{z}, 233 \mathrm{~m} / \mathrm{z}$, $205 \mathrm{~m} / \mathrm{z}, 163 \mathrm{~m} / \mathrm{z}$, dan $135 \mathrm{~m} / \mathrm{z}$.

\section{Penurunan kadar glukosa darah tikus}

Data penurunan kadar glukosa darah tikus Wistar putih sebelum dan setlah pemberian bahan uji fraksi etil asetat ekstrak daun sembung dapat dilihat pada Tabel 5.

Penelitian yang dilakukan selama tiga minggu menggunakan 20 tikus wistar putih berkelamin jantan dengan berat badan rerata 200 g. Secara anatomi, genetik, fisiologi dan gejala kondisi pada manusia dapat direplikasi ke tikus, hal ini menjadi alasan tikus sering digunakan dalam percobaan medis. Dua puluh ekor tikus dikelompokkan menjadi 5 kelompok, dimana tiap kelompok terdiri atas 4 ekor tikus. Hewan uji sebelum mendapatkan perlakuan diadaptasikan kemudian dipuasakan selama 8 jam tetapi tetap diberi minum secara ad libitum. Tujuan perlakuan ini agar pengaruh makanan pada saat pengukuran glukosa darah tidak mempengaruhi. Gula darah tikus wistar putih setelah puasa di uji untuk mengetahui kadar glukosa darah awal hewan uji (pretest). Kadar gula darah 70-110 mg/dL adalah kadar gula darah normal pada tikus Wistar putih. ${ }^{13}$

Tikus diinduksi dengan streptozotocin melalui intraperitonial menggunakan dosis tunggal $40 \mathrm{mg} / \mathrm{kgBB}$ agar hewan uji berada dalam keadaan diabetes. Menurut Wolfenshon, tikus dapat dikategorikan diabetes jika kadar glukosa darahnya $>135 \mathrm{mg} / \mathrm{dL}$. Kerusakan dari sel beta pankreas merupakan penyebab dari hiperglikemia. ${ }^{14}$ Streptozotocin menyebabkan kerusakan DNA pada islet pankreas dan menstimulasi poly adenosine diphosphate (ADP) ribosylation.

Pengujian normalitas diketahui bahwa data yang didapat terdistribusi normal $(p>0,05)$. Tes ini bertujuan mengetahui apakah data yang didapatkan dari setiap kelompok memiliki sebaran yang normal. Uji selanjutnya adalah Levene test yang berguna untuk mengetahui homogenitas setiap kelompok. Hasil uji menunjukkan data tiap kelompok yang didapatkan 
adalah homogen $(\mathrm{p}<0,05)$. Analis data dilanjutkan dengan uji One way ANOVA yang bertujuan untuk mengetahui pengaruh antara pemberian dosis fraksi etil asetat ektrak etanol daun sembung terhadap kadar gula darah tikus wistar yang hiperglikemia. Hasil uji One Way ANOVA menunjukkan nilai $(\mathrm{p}<0,05)$. Pernyataan ini mengindikasikan bahwa terdapat perbedaan yang berarti terhadap kadar glukosa darah tikus pada kelompok P1 dengan kelompok perlakuan (P2, P3, P4, dan P5) setelah diberikan fraksi etil asetat ektrak daun sembung.

Analisis statistik dilanjutkan pada uji LSD multiple comparisons (Post Hoc test), untuk mengetahui pengaruh antar tiap kelompok. Hasil uji LSD menyatakan kelompok P1 berbeda signifikan $(\mathrm{p}<0,05)$ terhadap kelompok P2, P3, P4 dan P5, ini karena tidak ada perlakuan yang diberikan sehingga kadar gula darah pada tikus wistar mengalami kenaikan yang signifikan. Perbedaan nyata $(\mathrm{p}<0,05)$ juga terdapat diantara kelompok P5 dengan P2, P3, dan P4. Kelompok P2 dan P3 belum bisa menyamai aktivitas penurunan glukosa darah kelompok P5, namun kelompok P4 sudah hampir menyamainya. Glibenclamide meningkatkan produksi dari insulin yang terdapat didalam sel $\beta$ pankreas sehingga kadar glukosa darah pada tikus Wistar yang hiperglikemia dapat normal lagi. Hasil ini menunjukkan ekstrak sembung dapat menurunkan kadar gula darah dari tikus wistar putih tapi tak sebesar dengan pemberian glibenclamide. Semakin besar jumlah dosis yang diberikan ke hewan uji menunjukkan penurunan kadar glukosa darah hewan uji makin besar juga.

Penurunan kadar gula darah pada tikus wistar yang hiperglikemia ini berasal dari senyawa flavoid yang terkandung pada ekstrak daun sembung itu. Hal ini didukung oleh beberapa penelitian salah satunya daun sembung memiliki sifat sebagai anti-hiperglikemia, antiobesitas, dan antioksidan yang berasal dari flavonoid dan alkaloid daun sembung. ${ }^{15}$ Jalur dari glukoneogenesis dan glikogenolisis yang tertekan disebabkan oleh peningkatan jalur glikogenik serta glikolitik yang berasal dari flavonoid yang bekerja diluar pankreas. ${ }^{16}$ Falvonoid bersifat sebagai antioksidan yang, mengikat radikal bebas dan merubahnya menjadi senyawa yang stabil. ${ }^{17}$

\section{SIMPULAN}

Pemberian ekstrak etanol daun sembung dengan dosis $50 \mathrm{mg} / \mathrm{kgbb}, 100 \mathrm{mg} / \mathrm{kgbb}$ dan $150 \mathrm{mg} / \mathrm{kgbb}$ secara intraperitoneal bermakna dapat menurunkan kadar glukosa darah pada tikus wistar yang hiperglikemia terhadap kontrol negatif.

\section{PERSETUJUAN ETIK}

Penelitian ini telah mendapatkan persetujuan dari Komite Etik Hewan Fakultas Kedokteran Hewan Universitas Udayana dengan nomor: 2451/ UN14.2.9/PD/2019.

\section{KONTRIBUSI PENULIS}

Penulis utama berkontribusi pada konsep, desain, defisini konten, telaah artikel, publikasi dan penanggung jawab. Penulis kedua berperan dalam telaah pustaka, studi eksperimental, pengambilan data, pengolahan data, analisis data, dan penyusunan manuskrip. Penulis ketika berperan dalam studi eksperimental, analisis data, dan telaah manuskrip.

\section{PENDANAAN}

Seluruh dana yang digunakan pada penelitian ini merupakan pendanaan pribadi oleh seluruh penulis.

\section{DAFTAR PUSTAKA}

1. PERKENI. Konsensus Pengelolaan Dislipidemia di Indonesia. Jakarta: Pusat Penerbitan Ilmu Penyakit Dalam Fakultas Kedokteran Universitas Indonesia. 2012.

2. Mulyani WRW, Sanjiwani MID, Sandra, Prabawa IPY, Lestari AAW, Wihandani DM, et al. Chaperone-Based Therapeutic Target Innovation: Heat Shock Protein 70 (HSP70) for Type 2 Diabetes Mellitus. Diabetes Metab Syndr Obes. 2020;13:559-568.

3. Butler AE, Janson J, Bonner-Weir S, Ritzel R, Rizza RA, Butler PC. $\beta$-cell deficit and increased $\beta$-cell apoptosis in humans with type 2 diabetes. Diabetes. 2003;52:102-110.

4. Kumar V, Cotran RS, Robbins SL. Buku Ajar Patologi Anatomi - Edisi 7 Vol. 2. Jakarta: EGC. 2007.

5. Arjadi F, Mustofa. Ektrak Daging Buah Mahkota Dewa Meregenerasi Sel Pulau Langerhans Pada Tikus Putih Diabetes. Jurnal Ilmiah Biologi Biogenesis. 2017;5(1):27-33.

6. Dalimartha S. Tanaman Obat di Lingkungan Sekitar. Jakarta: Puspa Swara. 2005.

7. Brahmachari G. Bio-Flavonoids With Promising Antidiabetic Potentials: A Critical Survey. Dalam: Vinod K, Tiwari and Bhuwan B, Mishra, editor. Opportunity, Challenge and Scope of Natural Products in Medicinal Chemistry - $1^{\text {st }}$ edition. Research Signpost. 2011:187-212.

8. Tarigan IM, Saiful B, Awaluddin S. Aktivitas Antihiperurisemia Ekstrak Etanol Herba Suruhan (Peperomia pellucida (L.) Kunth) Pada Mencit Jantan. Journal of Pharmaceutics and Pharmacology. 2012;1(1): 37-43.

9. Roy K, Saha S, Biswas S, Ahmed W, Mariappan G. In Vivo Assessment of Antidiabetic and Antioxidant Activities of Blumea Balsamifera in Streptozotocin-diabetic Rats. Journal of Medical Plant. 2013;7(1);48-57.

10. Lee DG, Mok S, Choi C, Cho EJ, Kim HY, Lee S. Analysis of Apigenin In Blumea balsamifera Linn DC. and Its Inhibitory Activity Against Aldose Reductase In Rat Lens. Journal of Agricultural Chemistry and Environment. 2012;1(1);28-33.

11. Pramesti G. Aplikasi SPSS 15,0 Dalam Model Linier Statistika. Jakarta: Elex Media Komputindo. 2007. 
12. Phongphaichit S, Nikom J, Rungjindamai N, Sakayaroj J. Biological activities of extract from endophytic fungi isolated from Garcinia plants. FEMS Immunol Med Microbial. 2008;51(3):517-25.

13. Ganong WF. Buku Ajar Fisiologi Kedokteran. Jakarta: EGC. 1995.

14. Wolfensohn S, Lloyd M. Handbook of Laboratory Animal Management and Welfare - 4th ed. West Sussex: WileyBlackwell. 2013.

15. Rahardjo SS. Review Tanaman Sembung (Blumea balsamifera [L.]) [Proceeding]. Samarinda: Seminar Nasional Tumbuhan Obat Indonesia ke-50. 2016.

16. Winarsi H. Antioksidan Alami dan Radikal Bebas, Potensi dan Aplikasinya dalam Kesehatan. Yogyakarta: Kanisius. 2007.
17. Panjuantiningrum, Feranose. Pengaruh Pemberian Buah Naga Merah (Hylocereus Polyrhizuz) Terhadap Kadar Glukosa Darah Tikus Putih Yang Diinduksi Aloksan [Skripsi]. Universitas Sebelas Maret: Surakarta. 2009.

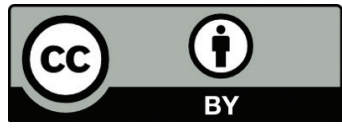

This work is licensed under a Creative Commons Attribution 